Article

\title{
Curcumin-Based Photodynamic Sterilization for Preservation of Fresh-Cut Hami Melon
}

\author{
Yilin Lin ${ }^{1,+}{ }^{+}$, Jiamiao Hu ${ }^{1,+}{ }^{\circledR}$, Shiyang Li ${ }^{1}$, Siti Sarah Hamzah ${ }^{2}$, Huiqin Jiang ${ }^{1}$, Arong Zhou ${ }^{1}$, \\ Shaoxiao Zeng ${ }^{1}$ and Shaoling Lin ${ }^{1, *}$ \\ 1 College of Food Science, Fujian Agriculture and Forestry University, Fuzhou 350002, Fujian, China \\ 2 Institute for Medical Research, Jalan Pahang, 50588 Kuala Lumpur, Malaysia \\ * Correspondence: shaoling.lin@fafu.edu.cn; Tel.: +86-15606025198 \\ + These authors contributed equally to this work.
}

Academic Editors: Derek J. McPhee and Francisco J. Barba

Received: 24 May 2019; Accepted: 25 June 2019; Published: 27 June 2019

\begin{abstract}
Fresh-cut fruits and vegetables are the main sources of foodborne illness outbreaks with implicated pathogens such as Escherichia coli O157:H7, Salmonella, and Listeria monocytogenes. This study aimed at investigating the influence of two key parameters (concentration of curcumin and illumination time) on the effects of curcumin-based photodynamic sterilization on the preservation of fresh-cut Hami melons. The results indicated that illumination with $50 \mu \mathrm{mol} / \mathrm{L}$ curcumin for $60 \mathrm{~min}$ using a blue LED lamp reduced the total aerobic microorganism count by $\sim 1.8 \log \mathrm{CFU} / \mathrm{g}$ in fresh-cut Hami melons. Besides this, the effects of photodynamic sterilization on the soluble solids content, color, water content, firmness, and sensory indices of the fresh-cut Hami melons were also evaluated. Compared to the control group, photodynamic sterilization can effectively delay the browning rate and maintain the luminosity, firmness, water content, and soluble solids content of fresh-cut Hami melon. The sensory quality was indeed preserved well after 9 days of storage in a fridge. These results showed that photodynamic sterilization is an effective and promising technology to prolong the shelf life of fresh-cut Hami melons.
\end{abstract}

Keywords: Hami melon; curcumin; photodynamic; colony number; storage quality

\section{Introduction}

Fruits are an integral part of our daily diet and are rich sources of vitamins, micronutrients, and antioxidants [1]. Driven by increasing demand for convenient, ready-to-eat foods, the market of fresh-cut fruits (also known as pre-cut fruits) has grown rapidly. However, alongside this trend, foodborne disease outbreaks associated with fresh fruits have also risen globally. Recent statistics showed that the pathogens that most frequently contribute to foodborne illness outbreaks linked to fresh fruits and vegetables are Escherichia coli O157:H7, Salmonella, and Listeria monocytogenes.

Hami melon (also known as cantaloupe) is a type of muskmelon, well known for its aesthetic appearance and sweet flavor. This melon is considered the "king of melons" [2]. Due to its richness in nutrients and good taste, Hami melon is a popular fruit item used to make fresh-cut fruits. However, mechanical damage during fresh-cut processing often destroys the tissues of Hami melon, leading to the loss of nutrients and aromatic odor. Furthermore, mechanical damage also facilitates microbial growth, speeding the process of fruit degradation [3]. In addition, the high sugar content of Hami melon further accelerates the growth of microorganisms, which greatly shortens its shelf life. Besides this, long storage periods will also cause fresh-cut fruits to lose water content and become brownish in color, degrading the taste [4].

Presently, a number of approaches including coating [5], ultra-violet and violet-blue light irradiation [6-8], modified atmosphere packaging [9], and chlorine dioxide treatment [10] have been 
developed for preserving fresh-cut fruits, but these processes are relatively expensive. Therefore, developing novel approaches that are cheaper alternatives for fresh-cut fruit preservation has great potential in the food industry [11].

Photodynamic sterilization technology (PDS) is an environmentally friendly, non-thermal sterilization method. The underlying mechanism involves photosensitizers being activated by lights of certain wavelengths and absorbing the energy of photons to produce reactive oxygen species. These active substances then kill pathogenic microorganisms without damaging the adjacent tissues and cells. PDS was originally used for treating malignant tumors [12], papillomatosis [13], endodontic infection [14], and blood product disinfection [15], and then successfully applied to foods in the 1980s $[16,17]$. Compared to traditional sterilization technology, PDS possesses a stronger germicidal effect and is less expensive. In addition, this novel technology may also preserve the respective color, fragrance, and freshness of the foods.

Currently, a number of novel photosensitizers have been identified or synthesized, including both antimicrobial and anti-cancer photosensitizers [18]. Among these photosensitizers, curcumin, a natural plant phenolic food additive, is widely used as a photosensitizer in PDS due to its low cost and safety $[17,19]$. Studies have already shown that the photodynamic action of curcumin can effectively kill malignant tumor cells [20-22]. Recently, scientists also demonstrated curcumin as a photosensitizer that can kill a range of pathogenic microorganisms in food even at low curcumin concentration $(25-100 \mu \mathrm{mol} / \mathrm{L})$ [23-26]. Furthermore, this method has already shown great potential in the preservation of fresh-cut fruits. For example, curcumin-mediated photodynamic sterilization was successfully applied in the preservation of fresh-cut "Fuji" apples [27]. Therefore, in this study, curcumin-mediated photodynamic treatment was conducted to determine its potential application for the preservation of fresh-cut Hami melon during storage at $4{ }^{\circ} \mathrm{C}$.

\section{Results and Discussion}

\subsection{Antibacterial Activity of PDS Treatment}

The effects of photosensitizer concentration and exposure time on the antibacterial activity of curcumin-mediated PDS for fresh-cut Hami melon preservation are shown in Tables 1 and 2. The data showed that the bacterial count of the fresh-cut Hami melon markedly increased with storage time. Meanwhile, the curcumin-mediated photodynamic treatment significantly dampened the bacterial growth compared to the control group $(p<0.05)$ (Tables 1 and 2). Illumination with $50 \mu \mathrm{mol} / \mathrm{L}$ curcumin decreased the bacterial count in the fresh-cut Hami melon from $3.97(\log \mathrm{CFU} / \mathrm{g})$ in the control group to $2.59(\log$ CFU/g) at 1 day post-treatment. This effect was still obvious till the ninth day of storage as evidenced by the decrease in the bacterial count from $6.81(\log C F U / g)$ in the control group to 4.95 (log CFU/g) in the fresh-cut Hami melon treated with $50 \mu \mathrm{mol} / \mathrm{L}$ curcumin and blue light, indicating that PDS treatment resulted in $\sim 1.8 \log$ CFU/g reduction when compared to the control after 9 days of storage (Table 1). These results showed that curcumin as a photosensitizer can effectively inhibit bacterial growth in fresh-cut Hami melon. Indeed, our results here are consistent with a previous report in which $2 \mu \mathrm{mol} / \mathrm{L}$ of curcumin and $510 \mathrm{~s}$ of illumination was demonstrated to reduce $E$. coli counts by 0.95 logs at $4{ }^{\circ} \mathrm{C}$ in fresh-cut apple [27]. 
Table 1. Effects of photosensitizer curcumin concentrations on the antibacterial activity of curcumin-based photodynamic sterilization for the preservation of fresh-cut Hami melons.

\begin{tabular}{|c|c|c|c|c|c|}
\hline \multirow{3}{*}{ Storage (day) } & \multicolumn{5}{|c|}{ Bacterial Count $(\log$ CFU/g) } \\
\hline & \multicolumn{5}{|c|}{ Curcumin Concentration } \\
\hline & $0 \mu \mathrm{mol} / \mathrm{L}$ & $10 \mu \mathrm{mol} / \mathrm{L}$ & $20 \mu \mathrm{mol} / \mathrm{L}$ & $40 \mu \mathrm{mol} / \mathrm{L}$ & $50 \mu \mathrm{mol} / \mathrm{L}$ \\
\hline 1 & $3.97 \pm 0.04^{\mathrm{a}}$ & $3.76 \pm 0.01^{b}$ & $3.04 \pm 0.11^{d}$ & $3.26 \pm 0.05^{c}$ & $2.59 \pm 0.09^{\mathrm{e}}$ \\
\hline 3 & $4.99 \pm 0.02^{\mathrm{a}}$ & $4.94 \pm 0.02^{\mathrm{a}}$ & $4.91 \pm 0.09^{b}$ & $4.67 \pm 0.01^{\mathrm{c}}$ & $3.81 \pm 0.01^{\mathrm{d}}$ \\
\hline 5 & $5.76 \pm 0.01^{\mathrm{a}}$ & $5.38 \pm 0.09^{b}$ & $5.23 \pm 0.07^{c}$ & $5.00 \pm 0.08^{d}$ & $4.23 \pm 0.03^{\mathrm{e}}$ \\
\hline 7 & $6.48 \pm 0.07^{\mathrm{a}}$ & $5.91 \pm 0.04^{b}$ & $5.75 \pm 0.02^{b}$ & $5.04 \pm 0.03^{c}$ & $4.77 \pm 0.04^{\mathrm{c}}$ \\
\hline 9 & $6.81 \pm 0.04^{\mathrm{a}}$ & $6.20 \pm 0.08^{b}$ & $5.87 \pm 0.05^{\mathrm{c}}$ & $5.11 \pm 0.07^{c}$ & $4.95 \pm 0.02^{\mathrm{c}}$ \\
\hline
\end{tabular}

Note: The data in the table indicate the mean \pm standard deviation, and significant differences exist among the data with different superscript letters in the same row $(p<0.05)$.

Table 2. Effects of different exposure time on the antibacterial activity of curcumin-based photodynamic sterilization for the preservation of fresh-cut Hami melons.

\begin{tabular}{|c|c|c|c|c|c|}
\hline \multirow{3}{*}{ Storage (day) } & \multicolumn{5}{|c|}{ Bacterial Count $(\log \mathrm{CFU} / \mathrm{g})$} \\
\hline & \multicolumn{5}{|c|}{ Exposure Time } \\
\hline & $0 \mathrm{~min}$ & $5 \mathrm{~min}$ & $30 \mathrm{~min}$ & $60 \mathrm{~min}$ & $90 \mathrm{~min}$ \\
\hline 1 & $3.54 \pm 0.03^{a}$ & $3.45 \pm 0.08^{b}$ & $3.28 \pm 0.01^{\mathrm{c}}$ & $2.65 \pm 0.04^{d}$ & $2.68 \pm 0.06^{\mathrm{d}}$ \\
\hline 3 & $4.98 \pm 0.02^{\mathrm{a}}$ & $4.26 \pm 0.01^{b}$ & $4.00 \pm 0.08^{c}$ & $3.67 \pm 0.02^{d}$ & $3.68 \pm 0.01^{d}$ \\
\hline 5 & $5.83 \pm 0.05^{\mathrm{a}}$ & $5.32 \pm 0.08^{b}$ & $4.94 \pm 0.12^{c}$ & $4.20 \pm 0.01^{\mathrm{c}}$ & $4.26 \pm 0.09^{c}$ \\
\hline 7 & $6.69 \pm 0.10^{a}$ & $5.99 \pm 0.11^{b}$ & $5.40 \pm 0.01^{c}$ & $4.61 \pm 0.07^{\mathrm{d}}$ & $4.65 \pm 0.08^{d}$ \\
\hline 9 & $6.72 \pm 0.07^{\mathrm{a}}$ & $6.11 \pm 0.10^{b}$ & $5.90 \pm 0.01^{b}$ & $4.86 \pm 0.08^{c}$ & $4.90 \pm 0.01^{\mathrm{c}}$ \\
\hline
\end{tabular}

Note: The data in the table indicate the mean \pm standard deviation, and significant differences exist among the data with different superscript letters in the same row $(p<0.05)$.

Hami melon samples sprayed with curcumin solution at $50 \mu \mathrm{mol} / \mathrm{L}$ and illuminated for different time periods were next analyzed for the photodynamic antibacterial effect. Generally, the germicidal efficacy increased with prolonged exposure time (Table 2), but beyond $60 \mathrm{~min}$, no further significant increases were obtained. Notably, even the shortest illumination time in our study ( $5 \mathrm{~min}$ ) already led to a significant decrease in the bacterial count compared to the control group $(p<0.05)$. Therefore, the optimal illumination time was chosen as 60 minutes, which was used throughout this study. In a previous study, similar findings were observed that the bacterial killing effect of PDS was more pronounced with prolonged illumination time but leveled off when irradiation time was further increased [28].

\subsection{Effects on Soluble Solids Content}

The soluble solid content is an important quality indicator of fresh-cut fruits during storage [29] and is closely associated with the flavor, taste, and nutrition of the fruits. As shown in Figure 1, the content of soluble solids in fresh-cut Hami melon decreased with increasing storage time in both the control and photodynamic-treated Hami melon samples (Figure 2). In the control group, the contents of soluble solids were $13.44 \%, 12.83 \%, 12.54 \%, 11.84 \%$, and $10.92 \%$ after 1 day, 3 days, 5 days, 7 days, and 9 days of storage, respectively. The indices of the contents of the soluble solids in the PDS-treated group after 1 day, 3 days, 5 days, 7 days, and 9 days of storage were 13.37\%, 13.14\%, $12.66 \%, 12.06 \%$, and $11.71 \%$, respectively. The contents of the soluble solids included sugar, acid, vitamins, and minerals which were influenced by a number of factors, including microbial metabolic activities [30]. Figure 1 indicates that PDS significantly changed the content of soluble solids compared to the control group only at Day $9(p<0.05)$. It is possible that microbial respiration affected by PDS, especially during long-term storage of the fruit, contributed to this phenomenon. Indeed, a previous study also demonstrated that applying an antimicrobial coating on fresh-cut mango not only inhibited 
the growth of microorganisms but also slowed down the decrease of the soluble solids content during storage [31].

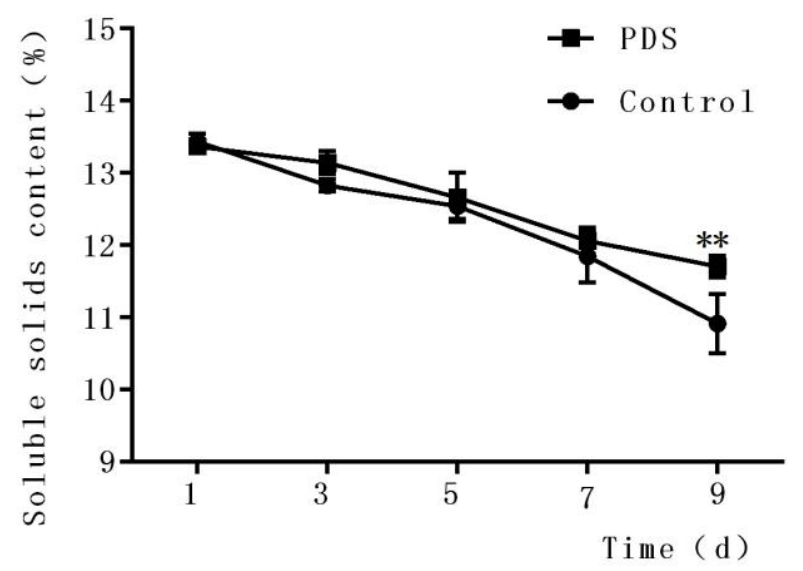

Figure 1. Effects of photodynamic sterilization (PDS) technology on the content of soluble solids in fresh-cut Hami melons. The PDS conditions included $50 \mu \mathrm{mol} / \mathrm{L}$ curcumin and $60 \mathrm{~min}$ of illumination with LED light. ${ }^{* *} p<0.01$ compared to the control group without photosensitizer and light treatment. Data points represent the mean and standard deviation of three experiments.

A

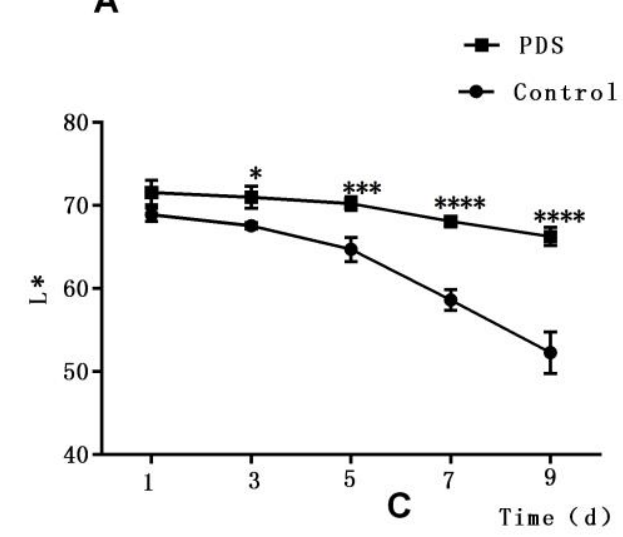

B

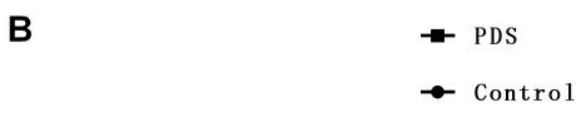

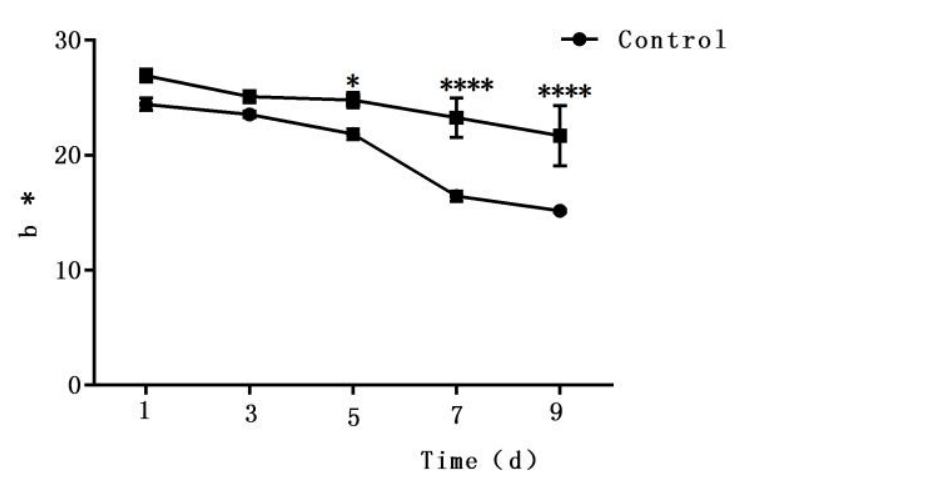

Figure 2. Effect of photodynamic sterilization technology on the $L^{*}$ (lightness) value (A), $a^{*}$ (redness) value $(\mathbf{B})$, and $\mathrm{b}^{*}$ (yellowness) value $(\mathbf{C})$ of fresh-cut Hami melons. The PDS conditions used were $50 \mu \mathrm{mol} / \mathrm{L}$ curcumin and $60 \mathrm{~min}$ exposure to LED light. ${ }^{*} p<0.05,{ }^{* *} p<0.01,{ }^{* * *} p<0.0005,{ }^{* * * *} p<0.0001$ compared to the control group without photosensitizer and light treatment. Data points represent the mean and standard deviation of three experiments. 


\subsection{Effects on Color}

Color is also an important characteristic which determines the sensory quality of fresh-cut fruits $[29,32]$. To quantify the color changes of fresh-cut Hami melon samples, the $L^{*} a^{*} b^{*}$ coordinates were measured, in which the $L^{*}$ value is the lightness of fruit, while the $a^{*}$ and $b^{*}$ values represent the redness and yellowness, respectively. As shown in Figure 2A, the $L^{*}$ values of the Hami melon samples decreased slowly during storage due to enzymatic browning on the cut surface. Besides this, the $\mathrm{L}^{*}$ values of samples with PDS treatment were slightly higher than those of the control group. Furthermore, the downward trend with a sharper slope in samples without PDS suggests that PDS can slow the reduction of the $L^{*}$ value in fresh-cut Hami melon. A similar phenomenon was also reported in a previous study in which results showed that PDS treatment may not only inhibit bacterial growth but also show anti-browning effects and prevent changes in the surface color of fresh-cut apple [27]. Besides this, the $\mathrm{a}^{*}$ (redness) value and $\mathrm{b}^{*}$ values (yellowness) of the fresh-cut Hami melon showed a similar pattern during storage, in which both decreased sharply after the fifth day (Figure 2B,C). Additionally, significant differences were also observed in the $\mathrm{a}^{*}$ and $\mathrm{b}^{*}$ values between the treated and control samples after 5 days of storage $(p<0.05)$. Taken together, these results demonstrate that PDS can effectively maintain the surface color of fresh-cut Hami melon throughout the storage period.

\subsection{Effects on the Water Content}

The water content of fresh-cut fruits is an important factor that influences the sensory quality and consumer perception [30]. In fact, it also affects the physiological metabolism of the fresh-cut fruits, in addition to making fresh-cut Hami melon stiff and full. As shown in Figure 3, the water content decreased under storage conditions. After 9 days of storage, the water contents decreased to $71.93 \%$ and $89.04 \%$ of the initial moisture content in the control and PDS-treated groups, respectively. The higher water content percentage in the photodynamically sterilized fresh-cut Hami melon might also result from, at least partially, the antibacterial effects of PDS. This can be explained by the fact that rapid microbial growth can result in reduced water content of the fruit. Similar results were also found by Tao et al., who reported that fresh-cut apple with PDS treatment showed less water loss during storage time compared to control samples [27]. These results suggest that PDS treatment may contribute to the maintenance of the water content in fresh-cut Hami melons during their storage.

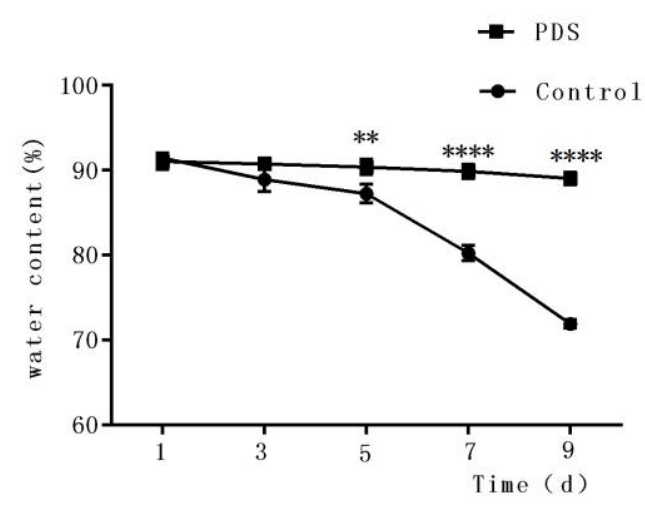

Figure 3. Effects of photodynamic sterilization technology on the water content of fresh-cut Hami melons. The PDS conditions used were $50 \mu \mathrm{mol} / \mathrm{L}$ curcumin and $60 \mathrm{~min}$ exposure to LED light. ${ }^{* *} p<0.01,{ }^{* * * *} p<0.0001$ compared to the control group without photosensitizer and light treatment. Data points represent the mean and standard deviation of three experiments.

\subsection{Effects on the Firmness}

Firmness is an important parameter reflecting the texture of a fruit $[29,32]$ and may be affected by the ripening, softening, and aging of the fruits [33]. As shown in Figure 4, during the first three days, an upward trend was observed in the firmness of the fresh-cut Hami melon, which may be due to 
an increase in toughness during storage. Then, the firmness of the fresh-cut Hami melon decreased with increasing storage duration. Several possible mechanisms may be related to this phenomenon, including the rapid growth of microorganisms which convert starch into soluble sugars, transforming the protopectin and pectin into pectic acids and destroying the spatial structure of Hami melon cells [34]. In addition, water loss may also cause the softening of Hami melon on the surface. Here, we also observed that the rate of decrease in firmness in the control group was significantly higher than that in the PDS group. A significant difference can be observed on the ninth day between the PDS-treated and control groups. The firmness in the PDS group was $9.79 \%$ higher than that in the control group $(p<0.05)$, suggesting that PDS can delay the decline of firmness in Hami melon. Indeed, a previous study demonstrated that 1-methylcyclopropene treatment inhibited the growth of microorganisms in fresh-cut Hami melon and suppressed its softening during storage [35], suggesting that slowing down the deterioration of fresh-cut Hami melon by inhibiting microorganisms may help to maintain its firmness.

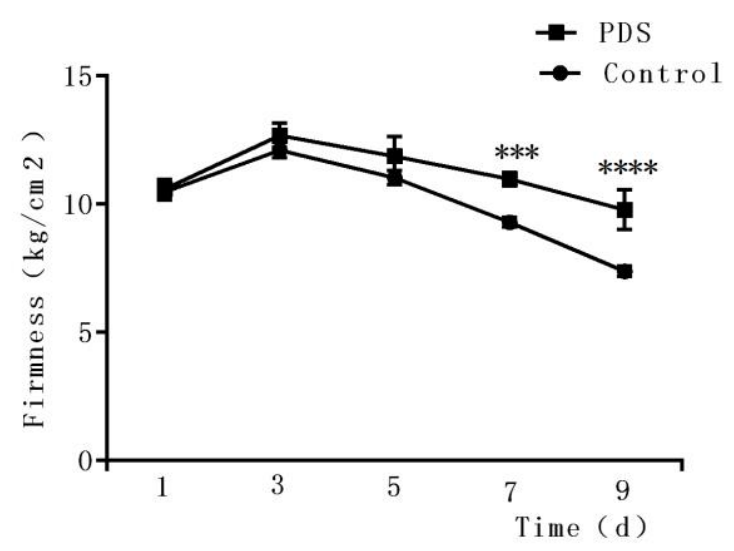

Figure 4. Effects of photodynamic sterilization technology on the firmness of fresh-cut Hami melons. The PDS conditions used were $50 \mu \mathrm{mol} / \mathrm{L}$ curcumin and 60 min exposure to LED light. ${ }^{* *} p<0.0005$, ${ }^{* * * *} p<0.0001$ compared to the control group without photosensitizer and light treatment. Data points represent the mean and standard deviation of three experiments.

\subsection{Effects on the Sensory Indices}

The sensory qualities of fresh-cut Hami melon, including color, smell, appearance, and mouthfeel (Table 3), were evaluated in the PDS-treated and control groups during storage (Figure 5). On the fifth day, the color and mouthfeel scores of the fresh-cut Hami melon were not significantly different between the two groups, while the scores of appearance and smell were significantly higher in the PDS-treated group than those in the control group (Figure 5A), and no samples were rotten across these two groups. With the increase in the storage time, the sensory indices of the fresh-cut Hami melon were significantly decreased (Figure 5B). On the ninth day, the scores of the smell and appearance of the fresh-cut Hami melon were higher in the PDS group than those in the control group (Figure 5B). In the control group, visible plaque appeared in the Hami melon, and the surface was softened and rotten, which decreased the quality of the Hami melon. Indeed, a number of studies have suggested that application of PDS treatment in food preservation can result in higher sensory scores upon storage [27,36]. In summary, photodynamic sterilization can effectively delay the deterioration of fresh-cut Hami melon. 
Table 3. Sensory and quality evaluation of fresh-cut Hami melon.

\begin{tabular}{ccccc}
\hline Score & Color & Flavor and Aroma & Surface & Feel \\
\hline 9 & Bright & $\begin{array}{c}\text { Characteristic } \\
\text { aroma }\end{array}$ & $\begin{array}{c}\text { Fresh, plaque-free, and no } \\
\text { softening. }\end{array}$ & $\begin{array}{c}\text { The flesh is firm, sweet, } \\
\text { crispy, and juicy. }\end{array}$ \\
\hline 7 & Slightly & Normal & $\begin{array}{c}\text { Fresh, no plaque, and no } \\
\text { softening, slight surface } \\
\text { water loss. }\end{array}$ & $\begin{array}{c}\text { The pulp is more compact, } \\
\text { harder, and crispy with a } \\
\text { thicker sweetness. }\end{array}$ \\
\hline 3 & Normal & Scented & $\begin{array}{c}\text { Lack of freshness, obvious } \\
\text { surface water loss, and } \\
\text { softening. }\end{array}$ & $\begin{array}{c}\text { The sweet taste is light, the } \\
\text { pulp is soft, less juice, and } \\
\text { not crispy. }\end{array}$ \\
\hline 1 & Dim & Loss of aroma & $\begin{array}{c}\text { Local diseased plaque and } \\
\text { touch with a slimy feeling. }\end{array}$ & Not edible. \\
\hline
\end{tabular}
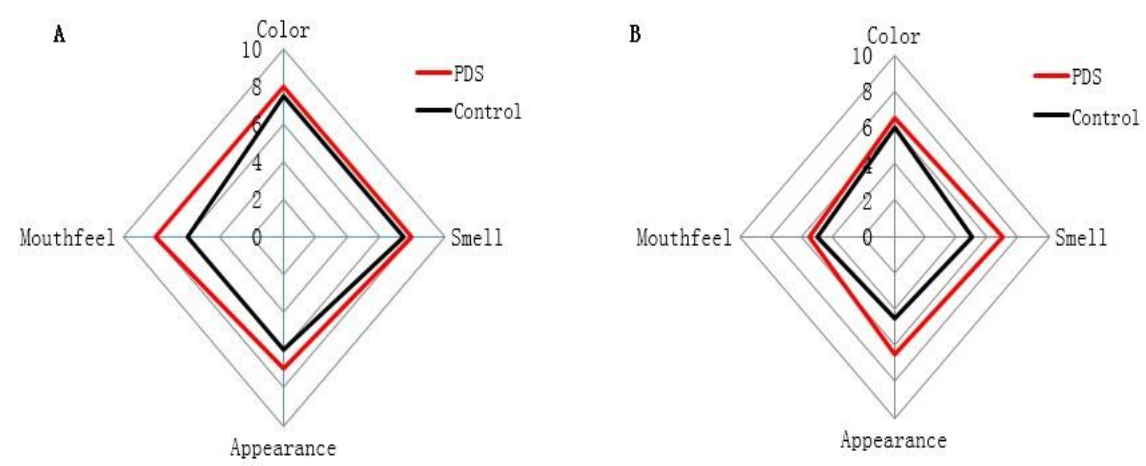

Figure 5. Effect of photodynamic sterilization technology on the sensory indices of fresh-cut Hami melons. The PDS conditions used were $50 \mu \mathrm{mol} / \mathrm{L}$ curcumin and $60 \mathrm{~min}$ exposure to LED light. (A) The sensory evaluation scores of fresh-cut Hami melon samples in the control groups and photodynamic treatment group after five days of storage. (B) The sensory evaluation scores of fresh-cut Hami melon samples in the control groups and photodynamic treatment group after nine days of storage.

\section{Materials and Methods}

\subsection{Preparation of Fresh-Cut Hami Melon}

Ripe Hami melon $(\sim 3 \mathrm{~kg})$ in pest-free condition was washed with water and disinfected with $0.21 \%$ sodium hypochlorite, followed by rinsing in distilled water. The Hami melon was peeled and then cut into 16 parts on a HEPA clean bench, placed into plastic boxes, and stored at $4{ }^{\circ} \mathrm{C}$ prior to PDS treatment within $2 \mathrm{~h}$.

\subsection{Photosensitizer and Light Source}

Curcumin was purchased from Hefei Bomei Biotechnology Co., Ltd. (Anhui, China). A curcumin stock solution was prepared at the concentration of $10 \mathrm{mmol} / \mathrm{L}$. A blue light-emitting diode with a maximum irradiation wavelength of $460 \mathrm{~nm}$ was used as light source in all PDS treatments.

\subsection{Photosensitizer and Irradiation}

Fresh-cut Hami melon was sprayed with curcumin solution at different concentrations (10-50 $\mu \mathrm{mol} / \mathrm{L}$ ) and then exposed to LED illumination for $60 \mathrm{~min}$ at room temperature. Saline was used instead of curcumin for the treatment of Hami melon in the control group. For the $50 \mu \mathrm{mol} / \mathrm{L}$ concentration of curcumin, the effect of LED illumination time ( $5 \mathrm{~min}, 30 \mathrm{~min}, 60 \mathrm{~min}$, and $90 \mathrm{~min}$ ) on the fresh-cut Hami melon was also evaluated. Then, the fresh-cut Hami melon was stored in the fridge at $4{ }^{\circ} \mathrm{C}$. 


\subsection{Microbiological Analyses}

The quantification of microorganisms (mainly live, aerobic bacteria) in the fresh-cut Hami melon was performed by the plate colony counting method according to a previous report [37]. Briefly, the samples $(\sim 5 \mathrm{~g})$ were homogenized in $100 \mathrm{~mL}$ sterile water, sequentially tenfold diluted, and inoculated on the bacteriological substrate plate count agar (PCA). After incubating for $48 \mathrm{~h}$ at $37^{\circ} \mathrm{C}$, the number of colonies was counted. The total number of surviving colonies on the plate was counted.

\subsection{Quality Characteristics and Sensory Evaluation}

The soluble solids of the fresh-cut Hami melon were evaluated using a WZ Hand-held saccharometer (Chennuo Biotechnology Co., Ltd., Shanghai, China) according to the manufacturer's instruction. The color of the fresh-cut Hami melon was measured using an ADCI full-automatic color difference instrument (ADCI, Beijing Chen Taike Instrument Technology Co., Ltd., Beijing, China). The changes of color were represented by values of $L^{*}$ (lightness from black (0) to white (100)), a* (redness from green (-) to red (+)), and $b^{*}$ (yellowness blue (-) to yellow (+)). The moisture content of the fresh-cut Hami melon was determined using an SFY-20A Halogen Rapid Moisture Analyzer (Shenzhen Guanya Electronic Technology Co., Ltd., Shenzhen, China). The firmness of the fresh-cut Hami melon was tested using a TA.XTplus texture apparatus equipped with a P5 cylindrical probe (Beijing Chen Taike Instrument Technology Co., Ltd.). The pre-test speed, test speed, and post-test speed was set to 5 $\mathrm{mm} / \mathrm{s}, 2 \mathrm{~mm} / \mathrm{s}$, and $2 \mathrm{~mm} / \mathrm{s}$, respectively. The nine-point evaluation method was used to evaluate the sensory scores, including the aroma, taste, and appearance of the fresh-cut Hami melon (Table 3).

\subsection{Statistical Analysis}

Results are presented as the mean \pm SEM for at least three independent experiments. Statistical significance was determined using Student's $t$-test when comparing two groups or using one-way ANOVA followed by post hoc Tukey's multiple comparisons when comparing three or more groups. The difference between the means was considered statistically significant when $p<0.05$. All statistical calculations were performed using GraphPad Prism 5.

\section{Conclusions}

Curcumin can be used as a photosensitizer in photodynamic sterilization for food preservation. Here, our results also showed that curcumin-mediated PDS can effectively sterilize residual bacterial contamination in fresh-cut Hami melon and delay their growth. The antibacterial property of the photodynamic sterilization was affected by the length of time of LED exposure and the curcumin concentration. The results showed that microbes in fresh-cut Hami melon could be effectively killed by $50 \mu \mathrm{mol} / \mathrm{L}$ of curcumin under exposure to the light from a blue LED lamp for $60 \mathrm{~min}$. A previous study demonstrated that in fresh-cut fruit with a neutral $\mathrm{pH}$, such as Hami melon (cantaloupe), bacteria are the main source of spoilage [38]. Therefore, the effects of PDS in preserving the fresh-cut Hami melon in our study may be largely due to its bactericidal activity. However, we cannot rule out that fungicidal activity may also be involved in this process. Furthermore, compared to the control group, color changes were also inhibited effectively by photodynamic sterilization. The firmness, water content, and soluble solid content in the fruits were more stable in the PDS-treated fresh-cut Hami melon. In addition, the sensory qualities of the fresh-cut Hami melon were effectively maintained. Therefore, photodynamic sterilization may be a promising technology that can be utilized conveniently for the preservation of fresh-cut Hami melon and of other fresh-cut fruits in industry.

Author Contributions: S.L. (Shaoling Lin) and S.Z. conceived and designed the experiments; Y.L. and S.L. (Shiyang Li) performed the experiments; Y.L., H.J. and A.Z. analyzed the data; Y.L., J.H. and S.S.H. wrote the manuscript. All authors read and approved the final manuscript.

Acknowledgments: The authors are grateful to the National Natural Science Foundation of China (31801649) and the China Postdoctoral Science Foundation (2018M63072, 2019) for their financial support. 
Conflicts of Interest: The authors declare no conflict of interest.

\section{References}

1. Meng, X.; Gao, Z.; Jiang, N. Recent Progress on Processing and Preservation Techniques of Fresh-cut Fruit. Storage Process 2008, 5, 004 .

2. Liu, L.; Chitrampalam, P.; Zhai, W.; Chen, Y.; Zhu, W.; Shi, B. Efficient plant regeneration in three cultivars of Hami melon [Cucumis melo L. ssp. melo convar. ameri (Pang.) Greb] via organogenesis. J. Jpn. Soc. Hortic. Sci. 2013, 88, 415-420.

3. Rawat, S. Food Spoilage: Microorganisms and their prevention. Asian. J. Plant. Sci. Res. 2015, 5, 47-56.

4. Toivonen, P.M.; Brummell, D.A. Biochemical bases of appearance and texture changes in fresh-cut fruit and vegetables. Postharvest Boil. Technol. 2008, 48, 1-14. [CrossRef]

5. Olivas, G.I.; Barbosa-Cánovas, G.V. Edible Coatings for Fresh-Cut Fruits. Crit. Rev. Food Sci. Nutr. 2005, 45, 657-670. [CrossRef]

6. Pan, Y.-G.; Zu, H. Effect of UV-C Radiation on the Quality of Fresh-cut Pineapples. Procedia Eng. 2012, 37, 113-119. [CrossRef]

7. Kim, M.-J.; Bang, W.S.; Yuk, H.-G. $405 \pm 5$ nm light emitting diode illumination causes photodynamic inactivation of Salmonella spp. on fresh-cut papaya without deterioration. Food Microbiol. 2017, 62, 124-132. [CrossRef]

8. MacLean, M.; McKenzie, K.; Anderson, J.; Gettinby, G.; MacGregor, S. 405 nm light technology for the inactivation of pathogens and its potential role for environmental disinfection and infection control. J. Hosp. Infect. 2014, 88, 1-11. [CrossRef]

9. Mahajan, P.; Oliveira, F.; Montanez, J.; Frias, J. Development of user-friendly software for design of modified atmosphere packaging for fresh and fresh-cut produce. Innov. Food Sci. Emerg. Technol. 2007, 8, 84-92. [CrossRef]

10. Guo, Q.; Lv, X.; Xu, F.; Zhang, Y.; Wang, J.; Lin, H.; Wu, B. Chlorine dioxide treatment decreases respiration and ethylene synthesis in fresh-cut 'H ami'melon fruit. Int. J. Food. Sci. Tech. 2013, 48, 1775-1782. [CrossRef]

11. Vega-Mercado, H.; Pothakamury, U.R.; Chang, F.-J.; Barbosa-Cánovas, G.V.; Swanson, B.G. Inactivation of Escherichia coli by combining $\mathrm{pH}$, ionic strength and pulsed electric fields hurdles. Food Res. Int. 1996, 29, 117-121. [CrossRef]

12. Brown, S.B.; A Brown, E.; Walker, I. The present and future role of photodynamic therapy in cancer treatment. Lancet Oncol. 2004, 5, 497-508. [CrossRef]

13. Hamblin, M.R.; Hasan, T. Photodynamic therapy: A new antimicrobial approach to infectious disease? Photochem. Photobiol. Sci. 2004, 3, 436-450. [CrossRef] [PubMed]

14. Sahyon, H.B.S.; da Silva, P.P.; de Oliveira, M.S.; Cintra, L.T.A.; Dezan-Júnior, E.; Gomes-Filho, J.E.; de Castilho Jacinto, R.; dos Santos, P.H.; Sivieri-Araujo, G. Influence of curcumin photosensitizer in photodynamic therapy on the mechanical properties and push-out bond strength of glass-fiber posts to intraradicular dentin. Photodiagn. Photodyn. 2019, 25, 376-381. [CrossRef] [PubMed]

15. Wainwright, M. The emerging chemistry of blood product disinfection. Chem. Soc. Rev. 2002, 31, 128-136. [CrossRef] [PubMed]

16. Maisch, T. Anti-microbial photodynamic therapy: Useful in the future? Chem. Soc. Rev. 2007, $22,83-91$. [CrossRef] [PubMed]

17. Penha, C.B.; Bonin, E.; Da Silva, A.F.; Hioka, N.; Zanqueta, É.B.; Nakamura, T.U.; Filho, B.A.D.A.; Campanerut-Sá, P.A.Z.; Mikcha, J.M.G. Photodynamic inactivation of foodborne and food spoilage bacteria by curcumin. LWT 2017, 76, 198-202. [CrossRef]

18. Abrahamse, H.; Hamblin, M.R. New photosensitizers for photodynamic therapy. Biochem. J. 2016, 473, 347-364. [CrossRef]

19. Rahamathullah, R.; Khairul, W.M.; Bulat, K.K.; Hussin, Z. Influence of curcumin as a natural photosensitizer in the conductive thin film of alkoxy cinnamoyl substituted thiourea. Main Group Chem. 2015, 14, 185-198. [CrossRef]

20. Hosseinzadeh, R.; Khorsandi, K. Methylene blue, curcumin and ion pairing nanoparticles effects on photodynamic therapy of MDA-MB-231 breast cancer cell. Photodiagnosis Photodyn. Ther. 2017, 18, 284-294. [CrossRef] 
21. Singh, S.P.; Sharma, M.; Gupta, P.K. Enhancement of phototoxicity of curcumin in human oral cancer cells using silica nanoparticles as delivery vehicle. Laser. Med. Sci. 2014, 29, 645-652. [CrossRef] [PubMed]

22. Cao, J.; Jia, L.; Zhou, H.-M.; Liu, Y.; Zhong, L.-F. Mitochondrial and Nuclear DNA Damage Induced by Curcumin in Human Hepatoma G2 Cells. Toxicol. Sci. 2006, 91, 476-483. [CrossRef] [PubMed]

23. Hu, J.; Lin, S.; Tan, B.K.; Hamzah, S.S.; Lin, Y.; Kong, Z.; Zhang, Y.; Zheng, B.; Zeng, S. Photodynamic inactivation of Burkholderia cepacia by curcumin in combination with EDTA. Food Res. Int. 2018, 111, 265-271. [CrossRef] [PubMed]

24. Tyagi, P.; Singh, M.; Kumari, H.; Kumari, A.; Mukhopadhyay, K. Bactericidal Activity of Curcumin I Is Associated with Damaging of Bacterial Membrane. PLOS ONE 2015, 10, e0121313. [CrossRef] [PubMed]

25. Gunes, H.; Gulen, D.; Mutlu, R.; Gumus, A.; Tas, T.; Topkaya, A.E. Antibacterial effects of curcumin: An in vitro minimum inhibitory concentration study. Toxicol. Ind. Health. 2016, 32, 246-250. [CrossRef] [PubMed]

26. Wu, J.; Hou, W.; Cao, B.; Zuo, T.; Xue, C.; Leung, A.W.; Xu, C.; Tang, Q.-J. Virucidal efficacy of treatment with photodynamically activated curcumin on murine norovirus bio-accumulated in oysters. Photodiagnosis Photodyn. Ther. 2015, 12, 385-392. [CrossRef]

27. Tao, R.; Zhang, F.; Juantang, Q.-; Xu, C.-S.; Ni, Z.-J.; Meng, X.-H. Effects of curcumin-based photodynamic treatment on the storage quality of fresh-cut apples. Food Chem. 2019, 274, 415-421. [CrossRef]

28. Thakuri, P.S.; Joshi, R.; Basnet, S.; Pandey, S.; Taujale, S.D.; Mishra, N. Antibacterial photodynamic therapy on Staphylococcus aureus and Pseudomonas aeruginosa in-vitro. Nepal Med Coll. J.: NMCJ 2011, 13, 281-284.

29. Mitcham, B.; Cantwell, M.; Kader, A. Methods for determining quality of fresh commodities. Perish. Handl. Newsl. 1996, 85, 1-5.

30. Kaddumukasa, P.P.; Imathiu, S.M.; Mathara, J.M.; Nakavuma, J.L. Influence of physicochemical parameters on storage stability: Microbiological quality of fresh unpasteurized fruit juices. Food Sci. Nutr. 2017, 5, 1098-1105. [CrossRef]

31. Alikhani, M. Enhancing safety and shelf life of fresh-cut mango by application of edible coatings and microencapsulation technique. Food Sci. Nutr. 2014, 2, 210-217. [CrossRef] [PubMed]

32. Ghavidel, R.A.; Davoodi, M.G.; Asl, A.F.A.; Tanoori, T.; Sheykholeslami, Z.; Sciences, C. Effect of selected edible coatings to extend shelf-life of fresh-cut apples. Int. J. Agric. Biol. 2013, 6, 1171.

33. Paniagua, C.; Posé, S.; Morris, V.J.; Kirby, A.R.; Quesada, M.A.; Mercado, J.A. Fruit softening and pectin disassembly: an overview of nanostructural pectin modifications assessed by atomic force microscopy. Ann. Bot. 2014, 114, 1375-1383. [CrossRef] [PubMed]

34. Subedi, P.; Walsh, K. Assessment of sugar and starch in intact banana and mango fruit by SWNIR spectroscopy. Postharvest Boil. Technol. 2011, 62, 238-245. [CrossRef]

35. Li, X.; Cao, S.; Zheng, Y.; Sun, A. 1-MCP suppresses ethylene biosynthesis and delays softening of 'Hami'melon during storage at ambient temperature. J. Sci. Food. Agric. 2011, 91, 2684-2688. [PubMed]

36. Liu, F.; Li, Z.; Cao, B.; Wu, J.; Wang, Y.; Xue, Y.; Xu, J.; Xue, C.; Tang, Q.J. The effect of a novel photodynamic activation method mediated by curcumin on oyster shelf life and quality. Food Res. Int. 2016, 87, 204-210. [CrossRef]

37. Fan, L.; Song, J. Microbial quality assessment methods for fresh-cut fruits and vegetables. Stewart Postharvest Rev. 2008, 4, 1-9.

38. Lamikanra, O.; Chen, J.C.; Banks, D.; Hunter, P.A. Biochemical and Microbial Changes during the Storage of Minimally Processed Cantaloupe. J. Agric. Food Chem. 2000, 48, 5955-5961. [CrossRef]

Sample Availability: Not available. 